\title{
The Campaign of Asad Bin Alfurat to Conquer Sicily
}

\author{
Sattam Zuheir Alkhateeb \\ Department of Basic Sciences, Maan College, Balqa Applied University, Ma'an, Jordan \\ Email: sattam.bau@edu.jo
}

How to cite this paper: Alkhateeb, S. Z. (2016). The Campaign of Asad Bin Alfurat to Conquer Sicily. Advances in Historical Studies, 5, 271-278.

http://dx.doi.org/10.4236/ahs.2016.55021

Received: August 16, 2016

Accepted: December 27, 2016

Published: December 30, 2016

Copyright $\odot 2016$ by author and Scientific Research Publishing Inc. This work is licensed under the Creative Commons Attribution International License (CC BY 4.0).

http://creativecommons.org/licenses/by/4.0/ (c) (i) Open Access

\begin{abstract}
This is a study of a campaign of several campaigns to liberate Islam nation from the Byzantine domination. It is the campaign of Asad bin Alfurat to conquer Sicily. Such campaign had been very important in the operation to conquer Sicily eventually. The study consisted of an introduction and prologue for the first campaigns against Sicily, the relations between both Sicily and Byzantines with Aghlabids state, followed by the motifs to conquer Sicily and preparation for the campaign, the battle of Marj Balata, then the movement of the campaign to Syracuse and the death of Asad bin Alfurat. The study concluded that governors of Africa had been sending the military campaigns to Sicily due to its importance as a logistic location for Islamic armies moving to Sicily, besides wiping out the threats of Romans in Sicily as well as to spread out Islam religion among the Sicilians. The campaign had been fulfilled but the operation had been halted upon the death of Asad bin Alfurat.
\end{abstract}

\section{Keywords}

Asad Bin Alfurat, Conquer Sicily, Campaign

\section{Introduction}

\subsection{The Early Islamic Campaigns against Sicily}

The first attempted invasion against Sicily had occurred during the reign of Mu'awiah bin Abi Sufain in Syria under the Caliphate of Othman bin Affan (mgbh). In 32 h/652 a.d, Mu'awiah had sent a campaign led by Mu'awiah bin Hudaij to invade Sicily. The campaign had raided the strongholds of Romans in Sicily and returned (Alblathiri, 1987). During the reign of Mu'awiah bin Abi Sufian as a Caliph (41 - 60 h/661-680 a.d), the governor of Africa, Mu'awiah bin Hudaij, had sent a campaign to invade Sicily in 46 h/666 a.d commanded by Qais bin Abdullah Alfuzari. The campaign had seized cap- 
tives and booties and returned to Africa (Alblathiri, 1983). In 49 h/669 a.d, Oqbah bin Nafi'e Alfihri, governor of Africa had invaded Sicily (Alblathiri, 1983). In 85 h/704 a.d the governor of Africa, Mousa bin Nussair, had sent a campaign led by his son Abdullah (Attalibi, 1985) then had sent another campaign in $86 \mathrm{~h} / 705$ a.d led by Almogheerah bin Abi Burdah Alabdi (Bin Khayat, 1985). After 86 h/705 a.d the Islamic campaigns had been halted due to the involvement of Muslim state in the conquest of Andalucia, Spain (Addouri, 1997). In $102 \mathrm{~h} / 720$ a.d the islamic campaigns had been resumed, where Yazeed bin Abi Muslim Alansari, governor of Africa; had sent Mohamad bin Aws Alansari to lead a campaign against Sicily, but it had been cancelled due to the demise of Yazd bin Muslim Alansari (Bin Athari, 1983).

In $105 \mathrm{~h} / 722$ a.d the governor of Afriqa, Bishr bin Safwan, had invaded Sicily in person, during the reign of Caliph Hisham bin Abdul Malik (105 - 125 h/723-742 a.d), where he dominated large quantities of booties (Bin Alatheer, 1982).

In 110 h/728 a.d, the governor of Afriqa, Obeidah bin Abdurrahman Alaslami, had sent a campaign led by Othman bin Abi Obeidah, where the commander had been fell in captivity (Bin Khayat, 1985). The governor had sent another campaign in $112 \mathrm{~h} / 730$ a.d led by Thabit bin Khaitham, and later he had sent a third campaign in $113 \mathrm{~h} / 731$ a.d led by Abdulmalik bin Qatan. The governor had repeated the campaign in $114 \mathrm{~h} / 731$ a.d led by bin Qatan where it had accomplished its goals and returned. In $115 \mathrm{~h} / 733$ a.d the last campaign sent by Obeidah bin Abdurrahman to invade Sicily had been led by Bakir bin Sowaid where he had clashed with the Romans in a naval battle in which the Romans had bombarded his boats and vessels by the fire.

In $116 \mathrm{~h} / 734$ a.d, the new governor of Afriaq, Obeidullah bin Alhobab, had sent a campaign led by Otheman bin Abi Obeidah, where large numbers of muslim soldiers had been fell in captivity (Bin Alatheer, 1982). Ibin Alhobab had sent another campaign in 118 h/736 a.d led by Qatam bin Awanah Alkalbi, where the campaign had encountered resistance and returned (Bin Khayat, 1985).

In 122 h/740 a.d., ibn Alhobab had launched a large campaign against Sicily, led by Habeeb bin Abi Obeidah bin Oqbah bin Nafi'e, where he had seized Syracuse and signed an agreement of reconciliation with the habitants against taxes paid by them to the Muslim leader (Bin Alatheer, 1982).

In 135 h/752 a.d, during the reign of Abbasids, Abdurrahman bin Habeeb had invaded Sicily (Bin Alatheer, 1982). After that, the campaigns against Sicily had been halted due to the involvement of Africa governors in suppressing the internal riots, until the emerging of Aghlabids state (Bin Alatheer, 1982).

The previous campaigns had attempted to invade Sicily to threat Roman strongholds and weaken their power as a reaction against the interventions and threats of Byzantines against Muslim states at the Mediterranean coasts in general, and North Africa coasts in specific.

\subsection{Pre-Domination Relations among Sicilians, Byzantines and Muslims}

After the Islamic campaigns had been halted in (135 H/752 a.d), Romans had been able 
to fortify Sicily through fortresses and strongholds (Bin Alatheer, 1982). Before discussing the conquer of Sicily by Aghlabids, it is noteworthy to indicate that those Aghlabids, who had established their state in Africa in the wake of (184 H/799 a.d.) which had held their names and had been a part of Abbassids Caliphate nominally, had built relations with Sicily represented by the agreement which had been made by Prince Ibrahim bin Alaghlab (Althahabi, 1986), the founder of Aghlabids, state, (184 - 196 h/799-811 a.d), and signed an agreement with Constantine the Patriarch of Sicily in 189 h/805 a.d, for ten years (Addouri, 1980). Such agreement had been brached by both parties in the time of Prince Abi Alabbas (Bin Alabbar, 1956) (196 - 201 h/811-816 a.d). The result had been a clashing between both parties in $197 \mathrm{~h} / 812$ a.d, where they had reached another agreement in 198 h/813 a.d for ten years between Prince Abi Ala'bbas and Gregori the patriarch of Sicily (Addouri, 1997). Both parties had agreed on the exchange of captives of war, the protection of each other natives (Addouri, 1968), as well as the provision that "If any Muslim enters Sicily and wants to exit the Roman should not restrict him" (Almaliki, 1983). In the time of Aghlabid Prince Ziadatullah the first (bin oqaal) (200 - $223 \mathrm{~h} / 816-837$ a.d), the agreement had been renewed with the same terms (Alansari, 1967).

\section{The Campaign of Asad Bin Alfurat to Conquer Sicily}

\subsection{Reasons for Invasion of Sicily}

The uncommitment of Byzantines to the agreement signed with Ziadatuallah bin Alaghlab in $198 \mathrm{~h} / 813 \mathrm{a}$.d had the major role in motivating Muslims to invade and conquer Sicily, where Romans had been violating the agreement through the leader of Byzantine army, Fimi, who had invaded the coasts of Africa and committed acts of looting and robbery as what had happened in $211 \mathrm{~h} / 826$ a.d (Bin Alatheer, 1982).

The internal riots of Byzantine Empire had a vital role in taking the decision by Alaghlabids to invade Sicily urgently. One of these riots had been the revolt of Thomas the Sicilian in Minor Asia where he had seized Constantinople, which had obliged the Byzantine Emperor Michael II (205 - 214 h/820-829 a.d) to withdraw his forces from the outskirts of his empire to protect his capital city.

Such procedure had weakened the forces of the Mediterranean and Sicily coasts, and had led to occupation of Cretes Island by the Muslim navy fleet which had been developed to enable Muslims to launch a campaign to conquer Sicily and protect the strategic cities of Muslims at the coasts of Mediterranean and Africa (Sha'erah, 1992).

One of the internal reasons in the Byzantine Empire which had urged the conquest of Sicily had been that Femi, the Admiral of Byzantine fleet at Sicily had been willing to declare the independence of Sicily, as a result of Thomas revolt. As the Emperor of Romans had been informed the intentions of Femi he had written to Constantine of Sicily to detain Femi who had been acknowledged and conquered Syracuse city. Constantine army had fought with Femi army who had achieved victory and conquered Catania city and assigned Blat as a governor of the city. But Blat had accorded with Michael II, his cousin and governor of Palermo city, to coupe against Femi and defeated him. 
Blat had conquered Syracuse, where Femi had fled to Africa and asked for help of Ziadatullah bin Alaghlab and surrendered his fleet to the Aghlabids state (Ahmad, 1992), providing that he would have been the deputy of Prince in Sicily when conquering it.

Femi also had made another offer to govern Sicily as an emperor with paying all taxes to the Aghlabids Prince (Sha'erah, 1992). On the other hand we find that Prince Ziadatullah bin Ibrahim bin Alaghlab had wiped out the internal revolts that had been made against him (201 - $223 \mathrm{~h} / 816-830$ a.d), where the most dangerous revolt had been the revolt of Ziad bin Sahl in 207 h/822 a.d. and the revolt of Amro bin Mo'awiah Alqaisi in (208 h/823 a.d) (Bin Athari, 1983). The deteriorating conditions of habitants in Sicily under the reign of Byzantine Empire had helped Alaghlabids to conquer Sicily (Almadani, 1985).

The historical sources had been contradicted on the reasons of Femi revolt. Some sources had mentioned that he had married to a beautiful nun, called Homenza, without her consent, so their brothers had complained to the Byzantine Emperor in Constantinople who orders the detaining of Femi and cutting his nose (Almadani, 1985). Other sources mentioned that the reason had been his ambitions to dominate Sicily as an emperor (Almadani, 1985).

It seems that his ambitions had been the main reason for declaring the revolt, where some historians had asserted that Femi had proposed the conquest of Sicily by Aghlabids army provided that he would have been an emperor of Sicily and pay the taxes to them or the Prince Zaidatullah would have been his deputy (Sha'erah, 1992).

Whatever the reasons for revolt had been, the opportunity had been ready to conquer Sicily by Aghlabids.

\subsection{The Council That Had Been Held to Discuss the Conquest of Sicily}

We have previously mentioned that both Aghlabids and Sicily had signed a truce agreement, which had included that if a Muslim captive wanted to exit Sicily, Romans should not reject his quest (Alhamawi, 1984). Femi had informed Prince Ziadatullah that there had been Muslim captives in Sicily, which had been considered a breaching of the agreement. Such information had been confirmed by the envoys of Sicily patriarch who had arrived in Africa after Femi sought refuge (Almadani, 1985).

Such situation had obliged Prince Ziadatullah to hold a meeting with the elite and scholars of Qairawan, especially both judges Asad bin Alfurat (Shamsulddin, 1972), and Abu Mehrez (Alhamawi, 1984), to discuss the subject of conciliation signed with Sicily and to get informed the request of Femi.

The council had been divided into two views. The first had been the minority who hadn't support a military action and hadn't advised it. Such party had been headed by judge Abu Mehrez who had suggested the collection of more information and taking more time to assure that the Byzantines had violated the convention (Almadani, 1985).

The second party had been enthusiastic for fighting and intervention as an opportunity available for the jihad for Allah Sake. This party had been headed by judge Asad bin Alfurat who had offered a solution for the convention problem, where he had con- 
sidered Femi and his team as ambassadors that their testifications could be accepted for the subject of captives (Assamerai, 1988). He had said: "by messengers we signed truce agreement with the Byzantines, and by messenger we can make them violators" (Bin Alabbar, 1956). He also had cited the Quranic verse: "and don't be inclined and call for peace while you are superior" (Holy Qura'n).

Upon these arguments the council had agreed upon going on the campaign to conquer Sicily. The Aghlabids had begun making arrangements to supply the Islamic army with weapons and materials, where the judge Asad bin Alfurat had been assigned as the commander of army (Alhamawi, 1984).

\subsection{Preparation for the Conquest Campaign}

Prince Ziadatullah had assigned the leadership of Sicily campaign to Asad bin Alfurat. The latter had said: "Oh my Prince. You want to prevent me from judgment to let me as a leader". The Prince had replied: "You will grasp both" (Alhamawi, 1984). So the ships had been loaded with weapons and ammunitions at Sousa shipyard (Assamerai, 1988), with 70 warshipsin (Alhimiyari, 1984) addition to the ships of Femi which had been loaded with 700 horses (Bin Athari, 1983). Historians had discussed the number of soldiers, with more than 10 thousand infantry men (Alhamawi, 1984) including 700 horsemen (Alhamaawi, 1984). These soldiers had been comprised of Arabs, whom Ibin Athari had pinpointed them as the Sheriffs of Africa, besides the soldiers of the Prince from Balqan, Barbar and Negros, who had been the local natives in North Africa, especially from Howara in Tripoli, as well as Zab tribes like Katama and Andalucians who sought refuge in North Africa after the revolt of Rabath at Cordoba in 202 h/818 a.d. The Soldiers had also included many scholars and Fuqaha who contributed to the campaign as a holy war, so the campaign had been prepared completely (Bin Athari, 1983).

\subsection{Campaign Launch}

When the leader of the campaign, Asad bin Alfurat, had asked for permission to launch the campaign, Prince Ziadatullah had approved his request and ordered a celebration escort by all classes of society from Arabs, Barbars and the Andalucians to accompany the campaign from Qairawan to Sousa (Alhamawi, 1984).

When Bin Alfurat had seen the people with him and around the army, along with the horses and drums, he had addressed them: "No God but Allah, No partner to Him, Oh people Neither my father nor my grandfather had been a leader, so I hadn't experienced what you had seen but by education, so make your extreme efforts to grasp the knowledge and write it down, that will benefit you in the life and divine day (Alhamawi, 1984).

Before navigation, Asad bin Alfurat had said to Femi: "Keep seperated, we don't need your help" (Addabagh, 1967) and added "let your soldiers wear head covers to distinct themselves so they can decept the enemy and protect themselves against them" (Addabagh, 1967). In this case Alnuwairi had said "Femi and his soldiers had been se- 
parated from the Muslim army" (Alnuwairi, 1333).

The fleet had launched its campaign from Tunisian Sousa on Saturday (15th of Rabbe' I in $212 \mathrm{~h} / 14$ th of June, 827 a.d.) (Alnuwairi, 1333). The fleet had arrived the borders of Mazir in Sicily after three days, and stayed for three another days without movement, while they hadn't been encountered by the enemy except one regiment of Femi soldiers (Alnuwairi, 1333).

\subsection{Battle of Marj Belata}

The Muslim army at Mazir had stayed for three days to collect information and send war teams to determine the sources of threat by the leader Belata who had been dominating Sicily. Through the services of spies and soldiers of Femi, the leader Asad bin Alfurat had known that Belata had constructed bunkers in the forts of a landscape called Belata landscape, or Mari Belata. Such Marj had divided the road between Mazir and Palermo into two equal distances (Alhamawi, 1984). The army of Byzantine had been about 150 thousand of soldiers (Alhamawi, 1984), so Asad has decided to attack them raising the flag. Asad had addressed the soldiers "Those are the foreigners of coast, those are your slaves, don't be afraid of them" (Alhamawi, 1984).

When the Muslim army had reached near Marj Belata, Asad had asked Femi and his soldiers not to intervene, and wear insignia over their clothes to avoid miss cognition. So Femi and his soldiers had worn some herbs and branches on their head as a camoflague (Alhamawi, 1984).

The battle among both parties had been rapid where Belata and his soldiers had been defeated (Alhamawi, 1984), and escaped to Cascriana then to Floria where he had been killed (Bin Alatheer, 1982).

The battle had happened in (17th of Rabee' 2, $212 \mathrm{~h} / 15$ th of July 827 a.d.) (Addouri, 1980). When the news of victory had been sent to Prince Ziadatuallh, he had written to the Abbasids Caliph, Alma'moun (198 - 218 h/813-833 a.d.) to congratulate him the grand victory (Alhamawi, 1984).

After the battle of Marj Balatah, the commander Asad bin Alfurat had returned to the army base at Mazir where he had assigned one of his officers to be a governor, Abu Zaki Alkanani. Then he had gone to Syracuse, the capital of Sicily via the Roman ancient road by the southern coast of Sicily (Bin Alatheeri, 1982).

During his march to Syracuse, Asd bin Alfurat and his army bypassed fort Cofrrado (Bin Alatheeri, 1982), where Femi had intended to treason Muslims, so he had sent letters to the habitants of Corrado and Syracuse to prepare for the war against Muslim army (Bin Alatheeri, 1982).

Asad had met with the patriarchs of Syracuse who had asked him the peace and safety as a matter of deception, so he had agreed against paying taxes by Syracuse habitants.

When Asad had perceived that he had been deceived by the patriarch, who had intended to win the time to fortify Syracuse, Asad had decided to seize it (Bin Alatheeri, 1982).

Vazilev attributes the agreement of truce by Asad to reorganize the army loaded with 
booties and captives (Sha'erah, 1992), but the Islamic sources had pinpointed the real reason. Asad had been waiting support from Africa and Andalucia (Bin Athari, 1983).

After they had fortified their city, the citizens of Syracuse rejected the truce (Bin Alatheeri, 1982), so Muslim army had seized it by sea and land (Bin Alatheeri, 1982) and bunt its ships (Bin Athari, 1983). The siege had lasted for a long time where citizens of Syracuse had collected their cattle's and food to their regions, where the Muslim soldiers had been obliged to eat their horses.

Such status had affected the morale of soldiers negatively (Alhamawi, 1984), where a Muslim soldier had asked Asad to return to Africa, because "the life of a Muslim man is far more important to us than all infidel people" (Alhamawi, 1984).

Asad had refused the request and said "I will not stop a campaign as soon the Muslims have much wealth and force" (Alhamawi, 1984), and ordered the soldiers to be lashed. The rest of the army with Asad had been about nine thousands only due to the losses of lives during battles and the garrisons he had left at the conquered locations (Alhamawi, 1984).

During the Siege, the support from Africa and Andalucia had reached (Bin Athari, 1983), while the Romans has sent supplies from Constantinople to Syracuse besides supports from Palermo where many of them had been killed in the ditches dug by Muslims (Bin Alatheer, 1982).

The Siege of Syracuse by Muslim army had been intensified until the citizens asked for peace but Muslims had refused. During this time a plagne had killed large number of Muslims including Asad bin Alfurat in 213 h/828 a.d. after ten months of Siege in which Syracuse had been nearly ready for surrender (Bin Alatheer, 1982).

\section{References}

Addabagh, A. bin M. A. (1967). Ma'alim Aliman Fi Ma'rifati Ahlil Qairawan (2nd ed., p. 21). Alahmadi, M. (Reviewed), Alkhanji Bookshop.

Addouri, T. (1968). History of Arabs in Sicily (p. 7). Beirut: Publication of Lebanese University.

Addouri, T. (1997) Studies in the History and Civilization of Arabs in Sicily (p. 12). Alkhoms, Liybia: University of Nassir.

Addouri, T. A. (1980). Sicily and Its Relations with Mediterranean States (p. 22). Dar Arrasheed, Iraq: Publications of Culture Ministry.

Ahmad, A. (1992). Tareekh Almaghrib Alarabi Alislami (p. 83). Publications of Damascus University.

Alblathiri, A. A. A. M. bin A. (1983). Albayan Almoghrib fi Akhbar Alandalos wal Maghrib (3rd ed., p. 18). Provencial, L. (Reviewed), Beirut: Dar althaqafa.

Alblathiri, A. bin Y. bin J. (1987). Futoh Alboldan (p. 229). Beirut: Alma'arif Corp.

Alhamawi, S. (1984). Mo'ajam Albuldan (p. 417). Beirut: Dar Sadir.

Alhimiyari, A. (1984). Abu Abdullah (p. 366). Arraudul Mi'tar fee Khabaril Aqtar, Maktabat Lobnan.

Almadani, A. (1985). Muslims in Sicily and Southern Italy (p. 57). National Foundation for Books.

Almaliki, A. A. M. (1983). Riyadh Annufous. Reviewed by Bashir Albakk-oush, Dar Almaghrib 
Alislami, Beirut, vol. 1, p. 270.

Alnuwairi, S. A. bin A. (1333). Nihayatul Arab Fi Fononil Ala-dab. Dar Alkotob Almisryah, 24, 355-356.

Althahabi, S. (1986). Siyar A'alam Alnubala'a (p. 128). Arrisalah Est,

Assamerai, K. (1988). The History of Arab Maghrib (p. 16). Mosul: dar Alkutob.

Assamerai, K. (1988). The History of Arab Maghrib. Mosul: dar Alkutob.

Attalibi, M. (1985). Addawaltul Aghlabiyah (p. 422). Beirut: Dar Algharb Alislami.

Bin Alabbar, A. A. (1956). Alhullato Alsaira’a (p. 168). Mu'nis, H. (Reviewed), Cairo.

Bin Alatheer, I. A. (1982). Alkamil Fi Altarikh (p. 146). Beirut: Dar Sader.

Bin Athari (1983). Abu Abdullah, Albayan Almoghrib fi Akhbar Alandaloswal Maghrib (3rd ed., p. 18). L. Provencial (Reviewed), Beirut: Dar althaqafa.

Bin Khayat, K. (1985). Attarikh, (History) (p. 292). Riyadh: Dar Teebah.

Sha'erah, M. (1992). Arab and Romans (p. 66). Egypt: Dar Alfikrul Arabi.

Shamsulddin, A. A. (1972). ibinkhillikan. WafiyatulA'ayanwaAnba'uzaman. Dar Sadir, Beirut, 3, 282.

Submit or recommend next manuscript to SCIRP and we will provide best service for you:

Accepting pre-submission inquiries through Email, Facebook, LinkedIn, Twitter, etc. A wide selection of journals (inclusive of 9 subjects, more than 200 journals)

Providing 24-hour high-quality service

User-friendly online submission system

Fair and swift peer-review system

Efficient typesetting and proofreading procedure

Display of the result of downloads and visits, as well as the number of cited articles Maximum dissemination of your research work

Submit your manuscript at: http://papersubmission.scirp.org/

Or contact ahs@scirp.org 